\title{
A Review of Dynamic Capabilities, Innovation Capabilities, Entrepreneurial Capabilities and Their Consequences
}

\author{
Hieu Minh VU ${ }^{1}$
}

Received: June 02, 2020 Revised: June 28, 2020 Accepted: July 09, 2020

\begin{abstract}
The paper proposes a conceptual model which provides direction for researchers to empirically establish the connections between dynamic capabilities, innovation capabilities, entrepreneurial capabilities and financial and strategic performance. The author uses systematic literature review process to select the articles used in this study. First, the present paper review and discuss some major contributions to the theories of dynamic capabilities, innovation capabilities, entrepreneurial capabilities and their consequences. The author seeks to highlight different understandings of the concepts to clarify the distinctions between them. Second, the conceptual model and propositions for future studies were developed. The proposed model highlights the different measures of dynamic capabilities, innovation capabilities, entrepreneurial capabilities and their consequences. The model with its associated propositions was developed base on limitations and gaps observed from past studies. It is focused on empirically testing the direct impact of dynamic capabilities, innovation capabilities, and entrepreneurial capabilities on the performance of SMEs in Vietnam. Nevertheless, the proposed model can be applied to similar situations in different contexts and countries. Further empirical testing of proposed model would contribute to enriching existing knowledge of dynamic capabilities, innovation capabilities and entrepreneurial capabilities within SMEs and how these capabilities foster superior performance.
\end{abstract}

Keywords: Dynamic Capabilities, Entrepreneurial Capabilities, Financial Performance, Innovation Capabilities, Strategic Performance

JEL Classification Code: M10, L25, L26

\section{Introduction}

There is a growing research interest on how firm capabilities promote competitiveness, business practice and performance. In the past scholars have focused on organisations' resources as a source of growth, competitive advantage and innovation (e.g., Penrose, 1959; Wernerfelt, 1984; Barney, 1991). Differences in firms' performance cannot be explained by the industry itself (Rumelt, 1991; McGahan \& Porter, 1997) but by differences in strategic

${ }^{1}$ First Author and Corresponding Author. Lecturer, Faculty of Business Administration, Van Lang University, Vietnam [Postal Address: 45 Nguyen Khac Nhu, Co Giang Ward, District 1, Ho Chi Minh, 700000,

Vietnam] Email: vuminhhieu@vanlanguni.edu.vn

() Copyright: The Author(s)

This is an Open Access article distributed under the terms of the Creative Commons Attribution Non-Commercial License (http://Creativecommons.org/licenses/by-nc/4.0/) which permits unrestricted noncommercial use, distribution, and reproduction in any medium, provided the original work is properly cited. capabilities (Eisenhardt \& Martin, 2000; Winter, 2003), in terms of how firms deploy resources and competences (Johnson et al., 2014). The concept of capabilities and resources are not the same (Amit \& Schoemaker, 1993). It is not enough for firms to control tangible or intangible resources to survive in the marketplace. To meet the demands from new markets, revolutionary changes in technology or new business models, firms need to renew themselves (Chakravarthy \& Doz, 1992) and be innovative. The ability to configure and reconfigure resources is important. There are several types of capabilities in the literature.

The present paper focuses on dynamic capabilities, innovation capabilities and entrepreneurial capabilities. Amit and Schoemaker (1993) argue that capabilities can be functional and rooted in specific areas of the firm. Dynamic capabilities explain the firm's ability to develop competitive advantage in the time of uncertainty and change (Teece et al., 1997). Dynamic capabilities are useful in coping with dynamic environments. According to Teece's (2014) dynamic capabilities involves sensing opportunities 
to meet customer needs, seizing opportunities to mobilize resources and capture value, and continued renewal through transformation. Extant literature shows several theoretical studies on dynamic capabilities (e.g., Teece et al., 1997; Eisenhardt \& Martin, 2000; Teece, 2014). Yet, we do not fully understand the relationship between dynamic capabilities and strategic performance in an emerging market such as Vietnam. Innovation capability is a firm's ability to mould and manage multiple capabilities (Lawson \& Samson, 2001). Innovation capability enables firms to integrate key capabilities and resource to successfully stimulate innovation. Few scholars have examined the role of entrepreneurial capability on new venture performance (e.g., Zahra et al., 2011; Zhang et al., 2009; Abdelgawad et al., 2013). Yet, there is a lack of consensus on the concept of entrepreneurial capability (Afzal et al., 2018).

Prior studies place less emphasis on the importance of using the firm's capabilities to keep them current and productive (Zollo \& Winter, 2002; Winter, 2003). To develop and optimise entrepreneurial capability, firms need to coordinate the mindsets and actions of managers to spot and exploit opportunities. Entrepreneurial capability facilitates the internal and external changes that enable firms to be competitive in the marketplace (Zahra et al., 2011). Thus, this paper $\mathrm{x}$-rays the relationship between dynamic capabilities, innovation capabilities, entrepreneurial capabilities their consequences. The objective of this study is to develop a Dynamic Capability-Innovation Capability-Entrepreneurial Capability-Performance link model and suggest propositions for validation of the proposed model. This objective is achieved by reviewing and discussing some central contributions to the literature on capabilities (dynamic capabilities, innovation capabilities and entrepreneurial capabilities). This paper is arranged as follows. In the following section, this paper presents an overview of the review of concepts of dynamic capabilities, innovation capabilities and entrepreneurial capabilities. Followed by the methodology used in this study. Finally, discussion, conclusions and limitations and suggestions for future research are presented.

\section{Literature Review}

\subsection{The Concept of Dynamic Capabilities}

Collis (1994) opine that dynamic capabilities are organizational capabilities that make it possible to transform ordinary capabilities over time. He adds that dynamic capabilities face three challenges; erosion, substitution and learning about higher-order capabilities over time. In the word of Teece, Pisano, and Shuen (1997), dynamic capabilities, connotes the ability of a firm to integrate, develop, and reconfigure internal and external competences to cope with fast-changing environments. According to Barreto (2010), dynamic capabilities are the firm's potential to systematically solve problems by sensing opportunities and making timely market-oriented decisions. Eisenhardt and Martin (2000) submitted that dynamic capabilities comprise of product development, strategic decision making and alliancing. They assert that these capabilities are identifiable, and the basic processes and activities are similar across firms but they are not equal across industries. Helfat et al. (2007) note that dynamic capability is the capacity of a firm to purposefully develop, expand or modify its resource base. Most literature reviews on the nature of dynamic capabilities (e.g., Wang \& Ahmed, 2007; Easterby-Smith et al., 2009; Breznik \& Hisrich, 2014) treat Teece et al. (1997) as the original definition of dynamic capabilities.

In light of Teece (2014), dynamic capabilities seek to match business opportunities and user needs by learning processes that are hard to copy. For analytical purposes, Teece (2007) notes that dynamic capabilities can be operationalised as the capacity (1) to sense and shape opportunities and threats, (2) to seize opportunities, and (3) to sustain competitiveness by improving, combining, protecting, and, when necessary, reconfiguring the business enterprise's resources. According to Teece (2007), sensing capability is the capacity of firms to constantly scan, spot, and explore opportunities across technologies and markets. In a fast-changing market, new information and knowledge can create opportunities for innovation. Sensing involves investment in research and development. Extant literature suggests that research activity promote a firm's knowledge and the ability of firms to evaluate the new information (Cohen \& Levinthal, 1990; Todorova \& Durisin, 2007).

Other studies demonstrate that externally available information and resources influence all innovation activities and the development of a firm (Yam et al., 2011). Integration capability is one of the three components of managerial functions which are relevant to dynamic capabilities (Teece et al., 1997). Structural complexity and the number of organizational units leads to an increase of transactional cost across organizational units (Teece, 2007). In this context, dynamic capability emphasizes more on optimising the transfer of technology/information between and among the various units in a firm. Indeed, integration facilitates learning, sharing of know-how and expertise through the transfer of technology and know-how within an organisation (Teece, 2014).

Integration capability focuses on both internal coordination and external integration activities such as integrating market and customer knowledge and integrating knowledge of emerging technologies (Iansiti \& Clark, 1994) and transforming resources into innovative outputs. Reconfiguration capability enables 
firms to maintain profitable growth by recombining and reconfiguring assets and organisational structures to adapt to changing markets and technologies. Reconfiguration capability support firms to maintain evolutionary fitness and enable them to escape from unfavourable path dependencies (Teece, 2007). Karim and Capron (2016) pointed out that reconfiguration capability includes activities such as adding, redeploying, recombining, or divesting resources or business units.

Adaptive capability suggests a firm's ability to quickly coordinate and reconfigure resources to respond to sudden environmental changes (Gibson \& Birkinshaw, 2004) while sustaining performance (Aggarwal, Posen, \& Workiewicz, 2015; Kaur \& Mehta, 2016). It has been argued that adaptive capability allows a firm to spot and leverage the opportunities emerging in the market (Tseng \& Lee, 2014; Hofer, Niehoff, $\&$ Wuehrer, 2015). Firms possessing adaptive capability learn faster (Akgün, Keskin, \& Byrne, 2012), quickly respond to changes in line with firm priorities (Wang \& Ahmed, 2007) and integrate external information into the knowledge base of the firm (Tseng \& Lee, 2014).

\subsection{The Concept of Innovation Capabilities}

The concept of innovation capabilities is confusing and is complementary to that of dynamic capabilities (Brezinik \& Hisrich, 2014). Wang and Ahmed (2007) use innovation, adaptive and absorptive capabilities to conceptualise innovation capabilities. Teece (2007) assert that selecting products and business models are two core business processes central to innovation. From strategic management stance, innovation and innovation capabilities can be an aspect of dynamic capabilities.

According to Lawson and Samson (2001), innovation capability connotes the ability to mould and manage several capabilities. Arguably, firms with innovation capability can integrate important capabilities and resources to successfully foster innovation. Indeed, a firm's reconfiguration capability promote continuous transformation and enable them to obtain new resources and capture innovation benefits. Other scholars have conceptualised innovation capabilities as consisting of marketing innovation, product innovation and process innovation capabilities (e.g., Camison \& VillarLopez, 2014; Nwachukwu, Chladkova, \& Olatunji, 2018). Product innovation capability allows firms to effectively change their resources into innovative offerings that are unique and are better in terms of quality to exceed customers' expectations (Camison \& Villar-Lopez, 2014). Process innovation capabilities are linked to a firm ability to improve its internal processes (Damanpour, Walker, \& Avellaneda, 2009) and reduce the cost of production (Damanpour, 2010) which foster superior performance.

\subsection{The Concept of Entrepreneurial Capabilities}

Extant literature suggests that entrepreneurial capabilities consists of four distinct and interrelated dimensions that focus on sensing, selecting, shaping, and synchronizing of opportunities (Birkinshaw, 2001; Bingham et al., 2007; Felin, Zenger, \& Tomsik, 2009). The sensing dimension is about spotting or envisioning market and technological opportunities within and outside an industry (Burgelman $\&$ Grove, 2007; Klein, 2008). Alert scanning and searching (Tang, Kacmar, \& Busenitz, 2012), experimenting (Dyer, Gregersen, \& Christensen, 2009), and imagining (Felin et al., 2009; Klein, 2008) are important mechanisms for sensing. Sensing opportunities can come from employees, managers and decision-making process of an organisation. Shaping connotes orchestrating of relationships among internally and externally available capabilities and resources for opportunity realization (e.g., Felin et al., 2009). Synchronizing focuses on simultaneous exploration and exploitation of opportunities and harmonizing a firm's actions with the speed of the environment (Bourgeois \& Eisenhardt, 1988; Eisenhardt, 1989). Synchronizing operates through three mechanisms: temporal heuristics focus on sequence, pace, and timing.

Procedural heuristics articulates process or actions for opportunity execution. Priority heuristics emphasizes the ranking of opportunities in terms of their importance for the firm (Bingham et al., 2007). Entrepreneurial capabilities co-evolve with the environment (Lewin \& Volberda, 1999; Volberda \& Lewin, 2003) and is developed through experience and reflection (Bingham et al., 2007). In this context, entrepreneurs can re-conceptualize their environments, identify changes and emerging opportunities. Considering the skills and resources needed by entrepreneurs, entrepreneurial capabilities must align with the dynamics of the ecosystems and opportunities being optimised. Other scholars suggest that entrepreneurial capabilities consist of several subtle human characteristics such as passion and selfachievement, integrity and commitment, ethical leadership and active learning and analysis (Ohyama, Braguinsky, \& Murphy, 2004; Cardon et al., 2005; Cardon et al., 2009; Tang, Kacmar, \& Busenitz, 2012).

\subsection{Empirical Review}

\subsubsection{Dynamic Capabilities and Its Consequences}

Chakrabarti, Vidal, and Mitchell (2011) demonstrated that the development of the institutional market environment influences the ability of firms to benefit from the reconfiguration of resources and businesses. The literature shows that the relationship between dynamic capabilities and competitive advantage of firms is unclear (e.g., Chaharmahali \& Siadat, 2010; Krzakiewicz, 2013). Some 
scholars opine that dynamic capabilities do not show the attributes of heterogeneity and hence cannot be a source of competitive edge (e.g., Zahra, Sapienza, \& Davidsson, 2006; Easterby-Smith \& Prieto, 2008; Ogunkoya et al., 2014) and that the impact of dynamic capabilities is limited (Zott, 2003) and indirect (Cepeda \& Vera, 2007; Nieves \& Haller, 2014). Other researchers argue that dynamic capabilities foster competitive advantage (e.g., Ambrosini \& Bowman, 2009; Arndt, 2011; Aramand \& Valliere, 2012; Li \& Liu, 2014; Wang et al., 2015; Lee, Wu, Kuo, \& Li, 2016) and technical performances (Yi, Han \& Cha, 2018). The author reason that dynamic capabilities promote competitiveness and enhance firm performance. Indeed, past studies that affirmed the connection between the individual dynamic capability and competitiveness are highlighted below.

Adaptive capability helps a firm to quickly adapt to the fastchanging environment (Kaehler, Busatto, Becker, Hansen, \& Santos, 2014), create value and survive in the marketplace (Rouse \& Ziestma, 2008). Thus, adaptive capability can enable a multinational firm to gain a competitive advantage (Dixon, Meyer, \& Day, 2013). Absorptive capability facilitates the transformation of new or acquired knowledge into usable knowledge that allows a firm to gain competitive advantage (Zhou \& Li, 2010; Adeniran \& Johnston, 2012) and strategic edge over competitors (Delmas, Hoffmann, \& Kuss, 2011; Duchek, 2013; Su, Ahlstrom, Li, \& Cheng, 2013). A firm ability to absorb external knowledge can lead to the firm achieving competitive advantage (Fogg, 2012). Even though researchers recognise that dynamic capabilities of the firm may positively contribute to firm performance. Yet, there is no strong empirically evidence in the literature that supports this notion (Hitt et al., 2001; Helfat et al., 2007). More so, most of the studies were conducted in developed countries. It will not be out of place to examine this subject in emerging market contexts.

\subsubsection{Innovation Capabilities and Its Consequences}

Extant literature suggests that innovation promote competitiveness and growth (e.g., Pitelis, 2009), performance (e.g., Cho \& Pucik, 2005; Lestari, Leon, Widyastuti, Brabo, $\&$ Putra, 2020) and firm's price to book value (Basuki, Pulungan, \& Udin, 2020). Firms need to deploy, mobilize, integrate and dynamically align their resources and capabilities to innovate and achieve competitive advantage (Liao, Kickul, \& Ma, 2009; Yam, Lo, Tang, \& Lau, 2011). In the study of Chinese firms, Guan and Ma (2003) found that innovative capabilities influence export performance. They concluded that export growth is associated with the total improvement of innovation capability dimensions, except for manufacturing capabilities. Keskin (2006) submitted that market orientation and learning impact positively on innovation capabilities in SMEs. Cabral (2010) reported that innovation capability is essential for firms to cope with the rapid-changing turbulent environment and to gain a competitive advantage.

Past studies have shown that firms with higher innovative capabilities outperform competitors, post higher profitability and survive in the marketplace for a long time (Alfirevic \& Talaja, 2013; Agbim et al., 2014; Alrubaiee, Alzubi, Hanandeh, \& Ali, 2015; Granados, 2015; Wijekoon \& Galahitiyawe, 2015). Other scholars suggest that different innovation capabilities such as marketing innovation capability (e.g., Nwachukwu et al., 2018), product innovation and process innovation capabilities (Camison \& Villar-Lopez, 2014) are important for firm success. More of that, innovation capabilities have positive impacts on financial performance (Hoang \& Ngoc, 2019). The findings of the study done by (Lee \& Xuan, 2019) suggest that manufacturing (i.e. technology and product innovation) is positive relation to the total factor productivity increase in the short-run and total output growth in the long-run. Also, promoting technology and innovation management and supporting R\&D subsidies may reduce the marginal cost of conducting $\mathrm{R} \& \mathrm{D}$ and increase the rate of technology and innovation management and R\&D activity.

\subsubsection{Entrepreneurial Capabilities and Its Consequences}

In the literature, entrepreneurial capability has been examined using two perspectives; institution and individual skill and knowledge. Afzal, Siddiqui, and Dutta (2018) examined the influence of entrepreneurial capabilities on innovation performance and new venture performance. They found that entrepreneurial capability dimensions of passion, integrity and commitment, leadership and management capability and learning capability have a positive impact on innovation performance. Further, entrepreneurial capabilities dimensions are positively associated with new venture performance and prior experience. Zahra and George (2002) reported that entrepreneurial capabilities promote organisational change. Burgelman and Grove, (2007) submitted that entrepreneurial capabilities induce change into the firm's environment to foster a competitive edge.

Entrepreneurial capability involves judgments and actions of an entrepreneur that contributes to reshaping and leveraging a firm's capability portfolio (Adner \& Helfat, 2003; Augier \& Teece, 2009), firm competitiveness and performance (Lestari, Leon, Widyastuti, Brabo, \& Putra, 2020). Entrepreneurship plays an important role in creating corporate capabilities as (e.g., marketing, R\&D, operations capability), has a positive effect on dynamic capability (Yi, Han, \& Cha, 2018). Empirical studies on entrepreneurial capability are scanty. The author reason that more studies will uncover the role entrepreneurial capability plays in promoting superior performance in varying contexts. 


\section{Research Methodology}

A systematic literature review was done to identify relevant articles within the entrepreneurship, innovation and strategic management literature. Systematic literature review method reduces bias through a comprehensive literature search (Tranfield, Denyer, \& Smart, 2003). The author conducted a search using the keywords, dynamic capabilities, innovation capabilities and entrepreneurial capabilities. The review focused on both qualitative and quantitative studies from 1959 to 2020. The author included studies that focussed on dynamic capabilities, innovation capabilities and entrepreneurial capabilities related concepts. In total 102 articles from EBSCO host, Google Scholar, Scopus and Web of Science databases were reviewed.

\section{Findings and Discussion}

Capabilities focus on how a firm optimise and align with environmental changes to gain competitive advantage. It shows an organisation ability to assess changes in market trends and share resources accordingly (Oktemgil \& Gordon, 1997). Thus, competitive advantage emanates from competitive behaviour and depend on strategic resources and capabilities owned and controlled by a firm (Nwachukwu \& Chladkova, 2019). Even though past studies have demonstrated a connection between the analysed concepts, competitive advantage and new venture performance. Yet, research that examines the relationships between dynamic capabilities, innovation capabilities, entrepreneurial capabilities, and financial and strategic performance simultaneously is still lacking.

Therefore, this study develops and presents a conceptual model and propositions to examine the direct and combine effects of dynamic capabilities, innovation capabilities, entrepreneurial capabilities, and their consequences (financial and strategic performance). Consequently, the proposed perspective will require further investigations into the relationship between dynamic capabilities, innovation capabilities, entrepreneurial capabilities and financial and strategic performance indicators. It is evident from the literature review that dynamic capabilities have three dimensions; integration capability, reconfiguration capability and adaptive capability. Innovation capabilities focus on product innovation capability, process innovation capability and marketing innovation capability. The present study focuses on human characteristics aspect of entrepreneurial capabilities (e.g. passion, self-achievement, integrity and commitment, and active learning and analysis). Consequences are operationalised based on Santo and Britos (2012) which measured financial performance with profitability and growth and strategic performance with customer satisfaction, employee satisfaction, social performance and environmental performance. The author anticipates that future empirical research will support the relationship between these variables and provide insight into the capabilities that can foster performance. Based on the literature review, the author makes the following propositions;

1. Dynamic capabilities will foster financial and strategic performance

1a. Integration capability will foster financial and strategic performance

1b. Reconfiguration capability will foster financial and strategic performance

1c. Adaptive capability will foster financial and strategic performance

2. Innovation capabilities will positively influence financial and strategic performance

2a. Product innovation capability will positively influence financial and strategic performance.

$2 b$. Process innovation capability will positively influence financial and strategic performance

2c. Marketing innovation capability will positively influence financial and strategic performance.

3. Entrepreneurial capabilities promote financial and strategic performance.

Building on literature, the author proposes a framework that draws on past studies to stimulate research agenda in strategic management (organisational capabilities) and entrepreneurship within Small and Medium Enterprises (SMEs) in the emerging market, particularly Vietnam. Figure 1 shows the proposed relationship between dynamic capabilities, innovation capabilities, entrepreneurial capabilities and performance. Based on Figure 1, this paper identifies three propositions in a bid to empirically test the relationships.

Where: DC- dynamic capability, INC- innovation capability, EC- entrepreneurial capability, IC- integration capability, RC- reconfiguration capability, AC- adaptive capability, PIC- product innovation capability, PSIC- process innovation capability, MIC- marketing innovation capability, PF- Performance, FP- financial performance, SP- strategic performance.

\section{Conclusions}

Firms can reduce inefficiencies and post superior performance by developing innovative capabilities. The proposed model highlights the different measures of dynamic capabilities, innovation capabilities, entrepreneurial capabilities and their consequences. The model with its associated propositions was developed base on limitations and gaps observed from past studies. It is focused on 


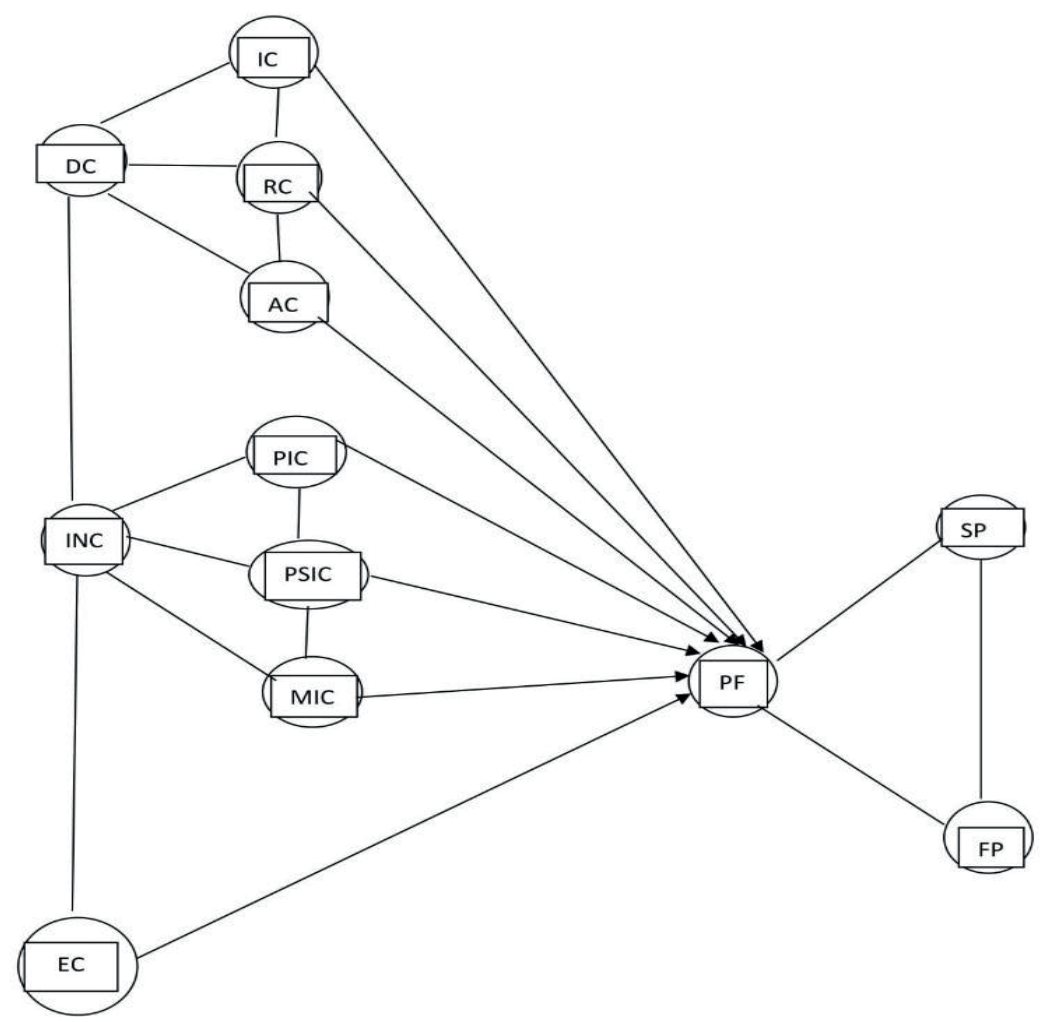

Figure 1: Conceptualization of dynamic capability, innovation capability, entrepreneurial capability-performance link proposed model.

empirically testing the direct impact of dynamic capabilities, innovation capabilities, entrepreneurial capabilities on the performance of SMEs in Vietnam. Nevertheless, the proposed model can be applied to similar situations in different contexts and countries. Further empirical testing of proposed model would contribute to enriching existing knowledge of dynamic capabilities, innovation capabilities and entrepreneurial capabilities within SMEs and how these capabilities foster superior performance. The author proposes that each of these capabilities consists of several multiple dimensions. Arguably, dynamic capability, innovation capability and entrepreneurial capability are important to changing the competitive game. Thus, adding to the existing literature explaining game change. The current paper sets an agenda for research on these issues and call for future empirical studies of how SMEs deploy their capabilities to enhance both financial and strategic performance.

\section{Limitations and Future Research Agenda}

The present study only developed a conceptual model and three main propositions for empirical testing. Future research should empirically test the goodness of fit and variables conceptualised in this study. Researchers need to empirically examine the connections between dynamic capability, innovation capability, entrepreneurial capability and performance. It would be interesting to ascertain if there are different types of dynamic capability, innovation capability and entrepreneurial capability; such variety could explain, the different strategic actions that firms pursue in their respective industries. It would be useful to explore how these different capabilities influence organisational adaptation, survival and performance. A five-point Likert scale ranging from $1=$ strongly disagree to 5 =strongly agree should be used to collect data from respondents. SmartPLS Structural equation Modelling (SEM) should be employed to test the relationship in the proposed research model. Smart PLS software is useful for prediction-oriented and exploratory study (Hair et al., 2016). More so, Smart PLS is suitable for simultaneously addressing multiple dependency associations with higher statistical efficiency (Ringle \& Sarstedt, 2016). 


\section{References}

Abdelgawad, S. G., Zahra, S. A., Svejenova, S., \& Sapienza, H. J. (2013). Strategic Leadership and Entrepreneurial Capability for Game Change. Journal of Leadership \& Organizational Studies, 20(4), 394-407. https://doi.org/10.1177/1548051813475484

Adeniran, T. V., \& Johnston, K. A. (2012). Investigating the dynamic capabilities and competitive advantage of South African SMEs. African Journal of Business Management, 6(11), 4088-4099. https://doi.org/10.5897/AJBM11.1673.

Adner, R., \& Helfat C. E. (2003). Corporate effects and dynamic managerial capabilities. Strategic Management Journal, 24(10), 1011-1025.

Afzal, M. N. I., Siddiqui, S. \& Dutta, S. (2018). Determinants of entrepreneurial capability (EC) environment in ASEAN-05 economies - a log-linear stochastic frontier analysis. Journal of Global Entrepreneurship Research, 8(14), 1-14. https://doi. org/10.1186/s40497-018-0101-y

Agbim, K. C., Zever, T. A., \& Oriarewo, G. O. (2014). Assessing the effect of knowledge acquisition on competitive advantage: A knowledge-based and resource-based study. Information and Knowledge Management, 4(11), 131-142.

Aggarwal, V. A., Posen, H. E., \& Workiewicz, M. (2015). Adaptive capacity and the dynamics of operational capabilities (pp. 1-40). INSEAD Working Paper Series No. 2015/09/EFE. Fontainebleau, France: INSEAD.

Akgün, A. E., Keskin, H., \& Byrne, J. (2012). Antecedents and contingent effects of organizational adaptive capability on firm product innovativeness. Journal of Production Innovation Management, 29(S1), 171-189. https://doi.org/10.1111/j.15405885.2012.00949.x.

Alfirevic, N., \& Talaja, A. (2013). Managing knowledge through dynamic capabilities. In: Soliman, F. (ed.), Learning models for innovation in organizations: Examining roles of knowledge transfer and human resources management (pp. 157-172). Hershey, PA: IGI Global. DOI: 10.4018/978-1-4666-4884-5. ch008

Alrubaiee, P., Al-zubi, H. M., Hanandeh, R., \& Ali, R. (2015). Investigating the relationship between knowledge management processes and organizational performance the mediating effect of organizational innovation. International Review of Management and Business Research, 4(4), 989-1009.

Ambrosini, V., \& Bowman, C. (2009). What are dynamic capabilities and are they a useful construct in strategic management? International Journal of Management Reviews, 11(1),29-49. https://doi.org/10.1111/j.1468-2370.2008.00251.x

Amit, R., \& Schoemaker, P. J. (1993). Strategic assets and organizational rent. Strategic Management Journal, 14(1), 33-46.

Aramand, M., \& Valliere, D. (2012). Dynamic capabilities in entrepreneurial firms: A case study approach. Journal of International Entrepreneurship, 10(2), 142-157. https://doi. org/10.1007/s10843-012-0088-3
Arndt, F. (2011). Assessing dynamic capabilities: Mintzberg's schools of thought. South African Journal of Business Management, 42(1), 1-9.

Augier, M., \& Teece, D. J. (2009). Dynamic capabilities and the role of managers in business strategy and economic performance. Organization Science, 20(2), 410-421. https://doi.org/10.1287/ orsc. 1090.0424

Barney, J. (1991). Firm Resources and Sustained Competitive Advantage. Journal of Management, 17(1), 99-120. https://doi. org/10.1177/014920639101700108

Barreto, I. (2010). Dynamic Capabilities: A Review of Past Research and an Agenda for the Future. Journal of Management, 36(1), 256-280. https://doi.org/10.1177/0149206309350776.

Basuki, B., Pulungan, N. A. F., \& Udin, U. (2020). The Effect of Innovation on Price to Book Value: The Role of Managerial Ownership in Indonesian Companies. Journal of Asian Finance, Economics and Business, (7)5, 249-258. https://doi. org/10.13106/jafeb.2020.vol7.no5.245

Bingham, C. B., Eisenhardt, K. M., \& Furr, N. R. (2007). What makes a process a capability? Heuristics, strategy, and effective capture of opportunities. Strategic Entrepreneurship Journal, $1(1-2), 27-47$.

Bourgeois, L. J., \& Eisenhardt, K. M. (1988). Strategic decision process in high velocity environments: Four cases in the microcomputer industry. Management Science, 34(7), 816-835.

Breznik, L. D., \& Hisrich, R. (2014). Dynamic capabilities vs. innovation capability: are they related?. Journal of Small Business and Enterprise Development, 21(3), 368-384. https:// doi.org/10.1108/JSBED-02-2014-0018

Breznik, L., \& Lahovnik, M. (2016). Dynamic capabilities and competitive advantage: Findings from case studies. Management: Journal of Contemporary Management Issues, 21(Special issue), 167-185.

Burgelman, R. A., \& Grove, A. S. (2007). Let chaos reign, then rein in chaos - repeatedly: Managing strategic dynamics for corporate longevity. Strategic Management Journal, 28, $965-$ 979. https://doi.org/10.1002/smj.625

Cabral, J. E. O. (2010). Firms' dynamic capabilities, innovative types and sustainability: A theoretical framework. Proceedings of XVI International Conference on Industrial Engineering and Operations Management (p. 12), Challenges and Maturity of Production Engineering: competitiveness of enterprises, working conditions, environment. São Carlos, SP, Brazil.

Camison, C., \& Villar-Lopez, A. (2014). Organizational innovation as an enabler of technological innovation capabilities and firm performance. Journal of Business Research, 67(1), 2891-2902. https://doi.org/10.1016/j.jbusres.2012.06.004

Cardon, M. S., Wincent, J., Singh, J., \& Drnovsek, M. (2009). The nature and experience of entrepreneurial passion. Academy of Management Review, 34(3), 511-532. https://doi.org/10.5465/ amr.2009.40633190

Cardon, M. S., Zietsma, C., Saparito, P., Matherned, B. P., \& Davis, C. (2005). A tale of passion: new insights into entrepreneurship 
from a parenthood metaphor. Journal of Business Venturing, 20(1), 23 - 45. https://doi.org/10.1016/j.jbusvent.2004.01.002

Cepeda, G., \& Vera, D. (2007). Dynamic capabilities and operational capabilities: A knowledge management perspective. Journal of Business Research, 60(5), 426-437. https://doi.org/10.1016/j. jbusres.2007.01.013

Chaharmahali, S. M., \& Siadat, S. A. (2010). Achieving organizational ambidexterity: Understanding and explaining ambidextrous organisation. Doctoral dissertation. Linköping, Sweden: Linköping University

Chakrabarti, A., Vidal, E., \& Mitchell, W. (2011). Business transformation in heterogeneous environments: The impact of market development and firm strength on retrenchment and growth reconfiguration. Global Strategy Journal, 1(1-2), 6-26. https://doi.org/10.1002/gsj.3

Chakravarthy, B. S., \& Doz, Y. (1992). Strategy process research: Focusing on corporate self-renewal. Strategic Management Journal, 13(S1), 5-14.

Cho, H. J., \& Pucik, V. (2005). Relationship between innovativeness, quality, growth, profitability, and market value. Strategic Management Journal, 26(6), 555-575. https://doi.org/10.1002/ smj.461.

Cohen, W. M., \& Levinthal, D. A. (1990). Absorptive capacity: Anew perspective on learning and innovation. Administrative Science Quarterly, 35(1), 128-152. https://doi.org/10.2307/2393553.

Collis, D. J. (1994). Research note: How valuable are organizational capabilities? Strategic Management Journal, 15, 143-152.

Damanpour, F. (2010). An Integration of Research Findings of Effects of Firm Size and Market Competition on Product and Process Innovations. British Journal of Management, 21(4), 996-1010. https://doi.org/10.1111/j.1467-8551.2009.00628.x

Damanpour, F., Walker, R. M., \& Avellaneda, C. N. (2009). Combinative Effects of Innovation Types and Organizational Performance: A Longitudinal Study of Service Organizations. Journal of Management Studies, 46(4), 650-675. https://doi. org/10.1111/j.1467-6486.2008.00814.x

Delmas, M., Hoffmann, V. H., \& Kuss, M. (2011). Under the Tip of the Iceberg: Absorptive Capacity, Environmental Strategy, and Competitive Advantage. Business \& Society, 50(1), 116-154. https://doi.org/10.1177/0007650310394400.

Dixon, S., Meyer, K., \& Day, M. (2013). Building dynamic capabilities of adaptation and innovation: A study of microfoundations in a transition economy. Long Range Planning, 47(4), 1-20.

Duchek, S. (2013). Capturing absorptive capacity: A critical review and future prospects. Schmalenbach Business Review, 65(3), 312-329. https://doi.org/10.1016/j.lrp.2013.08.011

Dyer, J. H., Gregersen H. B., \& Christensen C. M. (2009). The innovator's DNA. Harvard Business Review, 87(12), 60-67.

Easterby-Smith, M., Lyles, M. A., \& Peteraf, M. A. (2009). Dynamic capabilities: Current debates and future directions. British Journal of Management, 20(S1), S1-S8. https://doi. org/10.1111/j.1467-8551.2008.00609.x
Eisenhardt K. M. (1989). Making fast strategic decisions in highvelocity environments. Academy of Management Journal 32(3), 543-576. https://doi.org/10.2307/256434

Eisenhardt, K. M., \& Martin, J. A. (2000). Dynamic capabilities: What are they? Strategic Management Journal, 21(10-11), 1105-1121. https://doi.org/10.1002/10970266(200010/11)21:10/11<1105::AID-SMJ133>3.0.CO;2-E

Felin T., Zenger T. R., \& Tomsik, J. (2009). The knowledge economy: Emerging organizational forms, missing microfoundations, and key considerations for managing human capital. Human Resource Management, 48(4), 555-570. https:// doi.org/10.1002/hrm.20299.

Fogg, H. (2012). Tracing the links between absorptive capacity, university knowledge exchange and competitive advantage in SMEs. The International Journal of Entrepreneurship and Innovation, 13(1), 35-44. https://doi.org/10.5367/ ijei.2012.0061

Gibson, C. B., \& Birkinshaw, J. (2004). The antecedents, consequences, and mediating role of organizational ambidexterity. Academy of Management Journal, 47(2), 209226. https://doi.org/10.5465/20159573

Granados, M. L. (2015). Knowing what social enterprises know. 5th EMES International Research Conference on Social Enterprise (pp. 1-20). Retrieved from http:// westminsterresearch.wmin.ac.uk/16912/1/Knowing\%2520/ what $\% 2520$ Social $\% 2520$ Enterprises $\% 2520$ know.pdf

Guan, J., \& Ma, N. (2003). Innovative capability and export performance of Chinese firms. Technovation, 23(9), 737-747. https://doi.org/10.1016/S0166-4972(02)00013-5

Hair, J. F. Jr, Hult, G. T. M., Ringle, C., \& Sarstedt, M. (2016). A Primer on Partial Least Squares Structural Equation Modeling (PLS-SEM). New York, NY: Sage Publications.

Helfat, C. E., Finkelstein, S., Mitchell, W., Peteraf, M. A., Singh, H., Teece, D. J., \& Winter, S. G. (2007). Dynamic capabilities: understanding strategic change in organization. London, UK: Blackwell.

Hitt, M. A., Ireland, R. D., Camp, S. M., \& Sexton, D. L. (2001). Guest Editor's Introduction to the Special Issue Strategic Entrepreneurship: Entrepreneurial Strategies for Wealth Creation. Strategic Management Journal, 22, 479-491.

Hoang, C. C., \& Ngoc, B. H. (2019). The Relationship between Innovation Capability and Firm's Performance in Electronic Companies, Vietnam. Journal of Asian Finance, Economics and Business, 6(3), 295-304. https://doi.org/10.13106/jafeb.2019. vol6.no3.295.

Hofer, K. M., Niehoff, L. M., \& Wuehrer, G. A. (2015). The effects of dynamic capabilities on valued-based pricing and export performance. Entrepreneurship in International Marketing, 25, 109-127.https://doi.org/10.1108/S1474-797920140000025005

Iansiti, M., \& Clark, K. B. (1994). Integration and dynamic capability: Evidence from product development in automobiles and mainframe computers. Industrial and Corporate Change, 3(3), 557-605. https://doi.org/10.1093/icc/3.3.557 
Johnson, G., Whittington, R., Scholes, K., Angwin, D., \& Regnèr, P. (2014). Exploring Strategy Text \& Cases. Harlow, UK: Pearson Higher Education.

Kaehler, C., Busatto, F., Becker, G. V., Hansen, P. B., \& Santos, J. L. S. (2014). Relationship between adaptive capability and strategic orientation: an empirical study in a Brazilian company. iBusiness, 6, 1-9. DOI: 10.4236/ib.2014.61001

Karim, S., \& Capron, L. (2016). Reconfiguration: Adding, redeploying, recombining and divesting resources and business units. Strategic Management Journal, 37(13), 54-62. https:// doi.org/10.1002/smj.2537.

Karimi, J., \& Walter, Z. (2015). The role of dynamic capabilities in responding to digital disruption: A factor-based study of the newspaper industry. Journal of Management Information Systems, 32(1), 39-81. https://doi.org/10.1080/07421222.2015 .1029380

Kaur, V., \& Mehta, V. (2016). Leveraging Knowledge Processes for Building Higher-Order Dynamic Capabilities: An Empirical Evidence from IT Sector in India. The Journal of Indian Management \& Strategy, 21(3), 37-47.

Keskin, H. (2006). Market orientation, learning orientation, and innovation capabilities in SMEs: An extended model. European Journal of Innovation Management, 9(4), 396-417. https://doi. org/10.1108/14601060610707849

Klein, P. G. (2008). Opportunity discovery, entrepreneurial action, and economic organization. Strategic Entrepreneurship Journal, 2(3), 175-190. https://doi.org/10.1002/sej.50

Krzakiewicz, K. (2013). Dynamic capabilities and knowledge management. Management, 17(2), 1-15. https://doi. org/10.1111/j.1467-8551.2007.00543.x

Lawson, B., \& Samson, D. (2001). Developing innovation capability in organisations: A dynamic capabilities approach. International Journal of Innovation Management, 5(3), 377400. https://doi.org/10.1142/S1363919601000427

Lee, J. W., \& Xuan, Y. (2019). Effects of Technology and Innovation Management and Total Factor Productivity on the Economic Growth of China. Journal of Asian Finance, Economics and Business, 6(2), 63-73. https://doi.org/10.13106/jafeb.2019. vol6.no2.63

Lee, P., Wu, M., Kuo, C., \& Li, C. S. (2016). How to deploy multiunit organizations' dynamic capabilities? Management Decision, 54(4), 965-980. https://doi.org/10.1108/MD-052015-0160

Lestari, S. D, Leon, F. M., Widyastuti, S., Brabo, N. A., \& Putra, A. H. P. K. (2020). Antecedents and Consequences of Innovation and Business Strategy on Performance and Competitive Advantage of SMEs. Journal of Asian Finance, Economics and Business, 7(6), 365-378. https://doi.org/10.13106/jafeb.2020. vol7.no6.365

Lewin, A. Y., \& Volberda, H. W. (1999). Prolegomena on coevolution: A framework for research on strategy and new organizational forms. Organization Science, 10(5), 519-534.
Li, D. Y., \& Liu, J. (2014). Dynamic capabilities, environmental dynamism, and competitive advantage: Evidence from China. Journal of Business Research, 67(1), 2793-2799. https://doi. org/10.1016/j.jbusres.2012.08.007

Liao, S. H., Fei, W. C., \& Chen, C. C. (2007). Knowledge sharing, absorptive capacity, and innovation capability: An empirical study of Taiwan's knowledge-intensive industries. Journal of Information Science, 33(3), 340-359. https://doi. org/10.1177/0165551506070739

Lopez, S. V.(2005). Competitive advantage and strategy formulation: The key role of dynamic capabilities. Management Decision, 43(5), 661-669. https://doi.org/10.1108/00251740510597699

McGahan, A. M., \& Porter, M. E. (1997). How much does industry matter, really?. Strategic Management Journal, 18(S1), 15-30.

Nieves, J., \& Haller, S. (2014). Building dynamic capabilities through knowledge resources. Tourism Management, 40, 224232. https://doi.org/10.1016/j.tourman.2013.06.010.

Nwachukwu, C., \& Chladkova, H. (2019). Firm resources, strategic analysis capability and strategic performance: organisational structure as moderator. International Journal for Quality Research, 13(1), 75-94.

Nwachukwu, C., Chladkova, H., \& Olatunji, F. (2018). Strategy formulation process and innovation performance nexus. International Journal for Quality Research, 12(1), 147-164.

Ogunkoya, A., Hassan, B. A., \& Shobayo, P. A. (2014). Dynamic capabilities and competitive advantage: An analysis of the Nigerian banking sector. Journal of Accounting and Management, 4(2), 29-36.

Ohyama, A., S., \& Braguinsky, K. M. (2004). Murphy, Entrepreneurial ability and market selection in an infant industry: evidence from the Japanese cotton spinning industry. Review of Economic Dynamics, 7(2), 354-381. https://doi. org/10.1016/j.red.2003.08.002

Oktemgil, M., \& Gordon, G. (1997). Consequences of high and low adaptive capability in UK Companies. European Journal of Marketing, 31(7), 445-466. https://doi. org/10.1108/03090569710176619

Penrose, E. (1959). The theory of the growth of the firm. New York, NY: Oxford University Press.

Pitelis, C. N. (2009). The co-evolution of organizational value capture, value creation and sustainable advantage. Organization Studies, 30(10), 1115-1139. https://doi. org/10.1177/0170840609346977

Ringle, C. M., \& Sarstedt, M. (2016). Gain more insight from your PLS-SEM results: The importance-performance map analysis. Industrial Management \& Data Systems, 116(9), 1865-1886. https://doi.org/10.1108/IMDS-10-2015-0449

Rouse, M. J., \& Ziestma, C. (2008). Responding to weak signals: The emergence of adaptive dyanmic capabilities for strategic renewal. OLKC 2008, The International Conference on Organizational Learning, Knowledge and Capabilities (pp.123). Copenhagen, Denmark. 
Rumelt, R. P. (1991). How much does industry matter? Strategic Management Journal, 12(3), 167-185.

Santos, J. B., \& Brito, L. A. (2012). Toward a subjective measurement model for firm performance. Brazilian Administrative Review, 9(6), 95-117. https://doi.org/10.1590/ S1807-76922012000500007

Shane, S. (2000). Prior Knowledge and the Discovery of Entrepreneurial Opportunities. Organization Science, 11(4), 448-469. https://doi.org/10.1287/orsc.11.4.448.14602

Su, Z., Ahlstrom, D., Li, J., \& Cheng, D. (2013). Knowledge creation capability, absorptive capacity, and product innovativeness. $R \& D$ Management, 43(5), 473-486. https://doi.org/10.1111/ radm.12033

Tang, J., Kacmar, K. M. M., \& Busenitz, L. (2012). Entrepreneurial alertness in the pursuit of new opportunities. Journal of Business Venturing, 27(1), 77-94. https://doi.org/10.1016/j. jbusvent.2010.07.001

Teece, D. J. (2007). Explicating dynamic capabilities: the nature and microfoundations of (sustainable) enterprise performance. Strategic Management Journal, 28(13), 1319-1350. https://doi. org/10.1002/smj.640.

Teece, D. J. (2014). The foundations of enterprise performance: Dynamic and ordinary capabilities in an (economic) theory of firms. The Academy of Management Perspectives, 28(4), 328352. https://doi.org/10.5465/amp.2013.0116

Teece, D. J., Pisano, G., \& Shuen, A. (1997). Dynamic Capabilities and Strategic Management. Strategic Management Journal, 18(7), 509-533.

Todorova, G., \& Durisin, B. (2007). Absorptive Capacity: Valuing a Reconceptualization. The Academy of Management Review, 32(3), 774-786. doi:10.2307/20159334

Tranfield, D., Denyer, D., \& Smart, P. (2003). Towards a methodology for developing evidence-informed management knowledge by means of systematic review. British Journal of Management, 14(3), 207-222. https://doi.org/10.1111/14678551.00375

Tseng, S., \& Lee, P. (2014). The effect of knowledge management capability and dynamic capability on organizational performance. Journal of Enterprise Information Management, 27(2), 158-179. https://doi.org/10.1108/JEIM-05-2012-0025

Volberda, H. W., \& Lewin, A. Y. (2003). Guest editors' introduction co-evolutionary dynamics within and between firms: From evolution to co-evolution. Journal of Management Studies, 40(8), 2111-2136. https://doi.org/10.1046/j.14676486.2003.00414.x

Wang, C. L., \& Ahmed, P. K. (2007). Dynamic capabilities: A review and research agenda. International Journal of Management Reviews, 9(1), 31-51. https://doi.org/10.1111/ j.1468-2370.2007.00201.x

Wang, C. L., Senaratne, C., \& Rafiq, M. (2015). Success traps, dynamic capabilities and firm performance. British Journal of Management, 26(1), 26-44. https://doi.org/10.1111/14678551.12066

Wernerfelt, B. (1984). A resource-based view of the firm. Strategic Management Journal, 5(2), 171-180. https://doi.org/10.1002/ smj.4250050207

Wijekoon, A., \& Galahitiyawe, N. (2015). Innovativeness of Sri Lankan IT firms: The roles of knowledge management and dynamic innovation capabilities. 12th International Conference on Business Management (ICBM) 2015. http://dx.doi. org/10.2139/ssrn.2699756 .

Winter, S. G. (2003). Understanding dynamic capabilities. Strategic Management Journal, 24(10), 991-995. https://doi. org $/ 10.1002 / \mathrm{smj} .318$

Yam, R. C. M., Lo, W., Tang, E. P. Y., \& Lau, A. K. W. (2011). Analysis of sources of innovation, technological innovation capabilities, and performance: An empirical study of Hong Kong manufacturing industries. Research Policy, 40(3), 391402. https://doi.org/10.1016/j.respol.2010.10.013

Yi, H-T, Han, C-N., \& Cha, Y-B. (2018). The Effect of Entrepreneurship of SMEs on Corporate Capabilities, Dynamic Capability and Technical Performances in South Korea. Journal of Asian Finance, Economics and Business, 5(4), 135147. http://doi.org/10.13106/jafeb.2018.vol5.no4.135

Zahra, S. A., \& George, G. (2002). Absorptive capacity: A review, reconceptualization, and extension. Academy of Management Review, 27(2), 185-203.

Zahra, S. A., Abdelgawad, S. G., \& Tsang, E.W. K. (2011). Emerging Multinationals Venturing Into Developed Economies: Implications for Learning, Unlearning, and Entrepreneurial Capability. Journal of Management Inquiry, 20(3), 323-330. https://doi.org/10.1177/1056492611408266

Zahra, S. A., Sapienza, H. J., \& Davidsson, P. (2006). Entrepreneurship and dynamic capabilities: A review, model and research agenda. Journal of Management Studies, 43(4), 917-955. https://doi.org/10.1111/j.1467-6486.2006.00616.x

Zhang, M., Tansuhaj, P., \& McCullough, J. (2009). International entrepreneurial capability: The measurement and a comparison between born global firms and traditional exporters in China. Journal of International Entrepreneurship, 7, 292-322. https:// doi.org/10.1007/s10843-009-0042-1

Zhou, K. Z., \& Li, C. B. (2010). How strategic orientations influence the building of dynamic capability in emerging economies. Journal of Business Research, 63(3), 224-231. https://doi. org/10.1016/j.jbusres.2009.03.003

Zollo, M., \& Winter, S. G. (2002). Deliberate Learning and the Evolution of Dynamic Capabilities. Organization Science, 13, 339-351.

Zott, C. (2003). Dynamic capabilities and the emergence of intraindustry differential firm performance: Insights from a simulation study. Strategic Management Journal, 24(2), 97125. https://doi.org/10.1002/smj.288 